Covered in: ERIH PLUS, HeinOnline, CEEOL, Index Copernicus, CrossRef, CrossCheck, J-GATE, Google Scholar, Ideas RePeC, Econpapers, Socionet, KVK, WorldCat.

2018, Volume 6, Issue 2, pages: 14-25 | doi: https://doi.org/10.18662/lumenlaw/09

\section{The Need for} Specific and Unitary Regulations Regarding Techniques in Connection to or Derived from Medically Assisted Human

\section{Reproduction in Romania}

\section{Alexandra HUIDU1}

${ }^{1} \mathrm{PhD}$ Student, Doctoral School of Sociology of the University of Oradea, Oradea, Romania; LUMEN Research Center in Social and Humanistic Sciences, Iaşi, Romania, andra huidu@yahoo.com

\begin{abstract}
Currently, there is no law in Romania regulating how infertile patients can access medically assisted reproductive techniques, to expressly show whether some of these (the most controversial ones) are permitted or not (or we should apply the principle that everything that the law does not prohibit is allowed), under what conditions reproductive rights can be limited, what is the content of the right to reproduction, what is the legal status of the human embryo, and what are the limits of implementing certain medical procedure, whether we should just because they are available, or maybe it would be wiser not to. Discussions are further complicated when we bring into discussion some techniques that are related to assisted reproductive technologies (ART) (ie: those techniques or practices that have developed in parallel with in vitro fertilization, in order to facilitate the success of the technique surrogacy motherhood, sperm / egg donation, cryopreservation of surplus embryos, posthumous reproduction) or those techniques derived from ART (practices that have become possible due to the ability to create embryos outside the maternal womb - cloning, solo reproduction, embryonic stem cell research, genetic engineering for treating genetic diseases, non-therapeutic genetic engineering for physical or bio-moral improvement, special cases of genetic engineering: artificial embryos, sex selection, germline alteration, human-animal hybrids / chimeras). This paper arguments the necessity for elaborating specific normative regulations in the field of ART and techniques derived from or related to ART.
\end{abstract}

Keywords: medically assisted human reproduction; law on reproductive technologies; case law on human reproduction.

How to cite: Huidu, A. (2018). The Need for Specific and Unitary Regulations Regarding Techniques in Connection to or Derived from Medically Assisted Human Reproduction in Romania. Logos Universality Mentality Education Novelty: Law, 6(2), 14-25. https://doi.org/10.18662/lumenlaw/09 
The Need for Specific and Unitary Regulations Regarding Techniques in ...

\section{Introduction}

The low birth rate and the demographic decline is a reality in most of the EU countries and many of the economically stable countries outside the European Union. In Romania, according to data provided by the Romanian National Institute of Statistics (RNIS) in 1990, 67.660 more births than deaths were recorded in our country, but ever since 2014 the situation changed for the worse, because after 12 years of demographic decline Romania got to the point where the number of deaths is higher by 55.466 cases than the number of births (RNIS, 2012, Mihai \& Mirea, 2015) - the RNIS study was conducted for the period 1960-2010. Demographic studies conducted by the UN Statistical Division forecast a 15\% decrease in the population of Eastern Europe, including Romania, by 2023 (UNSD, 2016). If infertility was initially considered to be only a public health issue, recent statements made in the media by well-known academics and politicians qualify the issue of the declining birth rate in Romania as a problem of national security or long-term economic security. See, for example, the statements made by Ph.D professor Mircea Coşea (Academy of Economic Studies, Bucharest, Romania), former European Parliament member during January-December 2007 (Mihai \& Mirea, 2015). Vasile Ghețău, director of the Demographic Research Center of the Romanian Academy (Neagu, 2015), formulates a similar view.

In this context, infertility - as a stringent public health problem - has brought attention to medical assisted reproductive techniques (ART), especially in vitro fertilization (IVF), as an additional way (alongside a series of social policies to support increase in birth rates - policies on parental leave and indemnity, parental access to child-friendly services, tax deductions etc.) to tackle the demographic challenge faced by Romania. IVF seems to have become a medical procedure that is so popular in Romania in order to be considered a viable solution for the previously exposed issue, to such an extent that it is subject of a national health program.

IVF has become a common enough practice in Romania to attract the attention of the European IVF Monitoring Consortium of the European Society of Human Reproduction and Embryology - ESHRE), which included Romania in the European statistics referring to this medical technique. According to these statistics, in Romania, in 2009, 12 clinics provided in vitro fertilization services, with a total of 929 performed procedures, plus 110 procedures using cryopreserved embryos and 13 using donor-derived ovules, and in 2013 the number of clinics increased to 19, 
with 1839 IVF procedures performed, plus 538 with frozen embryos and 67 with donated eggs (Calhaz-Jorge, 2017; Farraretti et al., 2013).

Therefore, according to article 45 paragraph 1 of the Romanian Law no. 95/2006 on health reform, national health programs are designed for the purpose of preventing and treating medical conditions that have a major impact on the health status of the population. According to Government Decision no. 1388/2010 on the approval of national health programs for 2011 and 2012 (Chapter IV - "National Programs on Non-Infectious Diseases" - point 5 - "National Organ Transplantation of Organs, Tissues and Cells of Human Origin"), treating infertility as a national objective is the aim of subprogram 5.3 , entitled "In vitro fertilization subprogramme and embryo transfer" (similar provisions are contained in Government Decision no. 124/2013 on the approval of national health programs for 2013 and 2014, Government Decision no. 206/2015 on the approval of national health programs for years 2015 and 2016 and Government Decision no. 155/2017 on the approval of national health programs for 2017 and 2018).

In 2018, statistics show that in Romania 1 of 4 couples can not conceive naturally ("Mii de cupluri", n.d.), the estimated level of in vitro fertilization cycles per year is 5000 ("Bucureştencele care vor", 2018), and 5.259.800 lei from the state budget were allocated for the IVF-ET 2017 subprogram, which can be performed in 13 clinics registered in the program ("Fertilizare in vitro gratuită", n.d.).

\section{From social fenomenon to law}

While qualifying ART and techniques related to or derived from ART as primarily an important public health issue (as we have shown above), secondly, an aspect of long-term national economic interest (the problem of falling birth rates is one of the essential factors influencing the stability of the public pensions budget) and, thirdly, an area of controversial social relations and practices that need to be regulated by law in the shortest possible time, we show that the element that connects all of the above and which should lay the foundations for future actions is the need to create coherent public policies.

But creating public policies that genuinely support the needs and demands of a society can not be made without well-grounded arguments that indicate the particularities of the phenomenon in the community for which such social policies are being developed and the predictive trends in the evolution of the social phenomenon in the respective society. Then, based on the conclusions of sociological studies (which are a necessary first 
The Need for Specific and Unitary Regulations Regarding Techniques in ...

step) and on the (bio)ethical discourse (which is of interest given the controversial nature of some of these medical techniques), the principles underpinning these public policies will be developed. It is only then that the so-formulated public policies will be suitably reflected in the legal provisions to be enacted. Structuring the social and ethical discourse, as well as the conclusions that will be drawn based on it, are all the more important, as everything left out of the law will be governed by the rules of ethics. And abiding ethical norms in a society derives first of all from the degree of acceptability of that behavior in that particular society.

In vitro fertilization, through its basic process, the creation of embryos outside of the human body, has opened up the possibility of developing many practices or techniques related to the initial IVF technique. Thus, donation of gametes and surrogacy became possible in Romania as well. In Romania, sperm banks - for example, the Center for Assisted Human Reproduction at the Clinical Hospital Dr. Panait Sârbu from Bucharest ("Procedurile prin care trece", n.d.) - and oocyte banks (Creative Ideas, 2017) have already emerged. The Romanian courts have also faced disputes in which couples who have turned to surrogate mothers have requested for paternity and maternity to be granted in favor of the gamete providers and against the surrogate mothers and their spouses, presumed to be the fathers of the children according to the principle stated by article 53 of the Family Code, repealed by the New Civil Code, entered into force on 01.10.2011, but which maintains the same paternity presumption in article 414 - in this respect, the Timişoara Court of Appeals has pronounced Judgement no. 1196/2013 and Iasi Tribunal, Judgement no. 112/2001 (Barac, 2014).

Because they are a subject of ethical controversy, these practices have attracted virulent debates in Romanian society, because they create the possibility to have children not only for infertile couples, but rather for "disfertile" couples. The term "disfertile" was used for the first time by Cohen (2014), and it refers to those who are physically incapable to conceive (homosexual / lesbian couples and older couples). The problem was recently brought to the attention of the public opinion on March 24, 2018, when a public protest was organized in Oradea, where, according to data provided by Mediafax, about 8000 people participated in an event against recognizing marriage and reproductive rights to gay and lesbian couples ("Miting pentru familia tradițională", 2016). Subsequently, the Social Democratic Party's announcement the intention to organize a protest supporting the traditional family and against homosexual marriage, that was to be held in Bucharest in May 2018, but the event that has not yet taken place. Adriana Iliescu, a 66- 
year-old Romanian woman who gave birth to a girl in 2005, has become famous throughout the world, being enrolled in the Book of Records as the oldest woman in the world to give birth to a child (she became pregnant through IVF).

The IVF procedure, which usually involves creating an excess number of embryos than the ones that will be transferred in utero, raises the related problem of the fate of surplus embryos, in the sense of keeping them in cryopreservation for future implantations or donation, or using them in stem cell research, practices that give rise to heated controversy over the status of the human embryo, the dignity of the human being, the moment of the beginning of life, and the stage of evolution beyond which human life should benefit (or not) from legal protection. In 2014, there were already two clinics in Romania that provided services of cryopreservation of human embryos, sperm and oocites (Origyn Fertility Center, n.d.). The first stem cell bank in Romania was established in 2008, and now there are stem cell banks operating in 6 counties (Ungureanu, 2010). According to celulestem.ro (n.d.), in Romania, in 2018 there were three medical clinics where stem cell transplantation treatments could be made. The establishment of the first stem cell research center in Romania was announced in 2010 (Cojocaru, 2010). We synthesized the controversies about embryonic stem cell research in one of our previous research papers, entitled "The Ethics of Embryonic Stem Cells Research. The Human Being in the Early Stages of Development: A "Medicine" or End in Itself?" (Huidu, 2018a).

Methodological regulations for the development and reporting of specific activities in the IVF-ET Government funded health subprogram, according to Order no. 765/2011 issued by the Ministry of Health from Romania, expressly provide, at article 2.f, that funding from the state health insurance budget is granted only for married couples, that can obtain an embryo in vitro without oocyte or sperm donation or can obtain a pregnancy without a surrogate mother. The provisions are the same for all IVF-ET Subprograms (since the launch of the first such subprogram in 2011 and up to now), even though the New Civil Code, in Title III, Chapter II, Section 2, entitled Human Reproduction of Medically Assisted Reproduction with donor, allows donation of gametes and surrogate motherhood (from which we deduce that the legal prohibition is aimed not at these practices per se - if they are entirely financed by the infertile couple -, but enters into force only if the procedures are financed from the public insurance budget). 
The Need for Specific and Unitary Regulations Regarding Techniques in ...

Alexandra HUIDU

\section{The need to develop specific laws in the field of techniques related to or derived from ART}

As we can see from the information presented above, in vitro fertilization and practices related to IVF, which have been made possible by creating embryos in vitro, have grown at a social level in Romania over the past 10 years. In Romanian society, ART have stirred up various social responses, with replicas, arguments and reactions that occupied a wide range of manifestations between the two extremes: acceptance and rejection. We draw attention that the techniques described above are not even the most ethically controversial ones of ART-related technologies (but ethical controversies have a major impact on their acceptability at the social level).

At an international level, a range of medical techniques have implemented in medical practice which, although not currently available in clinics in Romania, could become a medical reality in our country in relatively short time. We refer to posthumous reproduction, pre-natal reproduction, non-therapeutic genetic engineering (to augment the physical features and abilities of the individual, including sex selection) and germline editing, which are currently possible and which, in the absence of any regulation prohibiting them in Romania, are predictable to be "imported" into Romanian society in the near future.

Posthumous reproduction is the situation when embryos created during the lifetime of both gamete providers and cryopreserved are implanted in the uterus and lead to the birth of a child after the death of one of the biological parents (Huidu, 2017: 218). On the one hand, it is considered that the right to procreate is a natural and inalienable right, which prevails over the child's interest in having a biparental family (ECASRM, 2004: 261), and on the other hand, it is considered that posthumous reproduction is an abnormal deviation of conscious and responsible reproduction, since it is against the interests of the future child, who will be orphaned by one or both parents even from the time of their birth (Simpson, 2001). Reproduction before birth involves the creation of a human embryo by the use of genetic material derived from stem cells taken from other embryos. The technique opens the possibility for a person to become a parent even before they are born, which may be a serious violation of the right not to procreate, as there is the possibility of altering the heredity laws, since the son / daughter may be older than father / mother (Huidu, 2017: 271). Germline gene altering involves genetic modifications of the human embryo through genetic engineering techniques, modifications that once made, will be passed on to the offspring of the individual. These 
techniques can give rise to far more intense social reactions (whether we discuss their acceptance or rejection) than those described in the first part of this article, and so they deserve special attention from the legislator.

Other medical techniques, that are still at an experimental or research stage worldwide, will raise new ethical and social acceptability dilemmas once they become practicable techniques (reproductive cloning, human- animal chimeras or hybrids, cognitive or moral bio-enhancement) and Romanian society will have to integrate them (or not) into the structure of traditional social relations at that moment, regardless of whether it will be prepared or not.

In a series of older studies (Huidu, 2009; Cuc, Huidu, \& Huidu, 2010; Huidu \& Cuc, 2009), we have extensively explained the need for the Romanian legislator to adopt legislation dedicated to these innovative medical techniques. At that time, we presented the ethical controversies regarding new reproductive technologies and their related techniques, we reviewed the international regulations in the field of ART (conventions, regulations, recommendations), as well as the national laws of the states that have legislated ART, we have shown why current regulations in Romania are not sufficient enough to ensure that the risks involved in these technologies are avoided and so we have tried to propose a series of regulatory models compatible with the legal tradition of Romania (as we already see, the legal situation in Romania has not changed significantly in the last 10 years). In a recent paper (Huidu, 2018b), we have joined the view of the international bioethical doctrine (Franklin \& Chapman, 2000), according to which, even if some techniques are still far from being applicable to a large scale, ethical debates and, implicitly, lawmaking must come before medical success, since once one technique becomes available, it will be more difficult to balance interests and reactions (economic, medical and, why not, emotional) inside society, unless some guidelines are drawn early.

In the above-mentioned papers, however, we have only touched a point that we want to outline below: any future law on ART and its related techniques must meet a number of desiderata:

1. it should be based on coherent and unitary social policies, suggested by sociological studies indicating the peculiarities of the phenomenon in Romania, to determine whether these techniques are known at the level of the Romanian society, and if so, we should discuss whether we have a superficial awareness or a profound knowledge of the risks involved in techniques related to ART, that would enable individuals to make valuable judgments about the opportunity that they should resort to such techniques 
The Need for Specific and Unitary Regulations Regarding Techniques in ...

or not, if they ever find themselves in a situation of reproductive vulnerability with particular emotional burden;

2. it should transpose existing practices and principles widely accepted in society, because a law must not be contrary to them, nor impose trends outside those specific for the level of development of a society at a certain point in time, nor aggravate social relations, nor leave room for dangerous digressions (social acceptability is also measured by sociological studies);

3. it should correctly balance the interests involved in respecting the principle of fair distribution of medical resources, as some of these techniques, due to their innovativeness, are or will be particularly high-cost, and at present not even the best private health insurance packages settle emerging, risky, cutting-edge genetic therapies or medical techniques derived from ART;

4. any legal bans in the field of ART or medical research of ART techniques must be based on sound, reasoned and sociologically substantiated and ethically sound, human rights-based arguments, in order to create applicable laws without producing virulent responses across society, while maintaining a fine balance between individual interests and those of society as a whole;

5. any law must regulate not only for the present, but also establish a predictive line, as far as possible, in the area in which it operates, to be readily adaptable to the evolution of medical technologies, and to provide guidelines, at least principally, for future situations that are not realities of the present, but can become practices of the future.

\section{Conclusions}

According to the arguments we mentioned above, we can conclude that there is a need to develop methods of analysis of the phenomenon of the social use and acceptability of the techniques related to or derived from ART, as a basis for elaborating coherent and assumed policies in the field, reflected in future laws. Starting from here, we draw attention to the fact that Romania has to align them with the laws of the EU Member States or non-EU states, but with tradition in the field of the ART regulations, in order not to repeat the unfortunate experiences of these states, which cover a wide rage of problems, like being transit countries in medical tourism or a haven for unethical research on human embryos or human subjects.

Also, based on the spirit of social solidarity, it is also necessary to establish clearly the criteria for granting public funding for the medical 
treatment of infertility through innovative techniques, determining the status of the human embryo created in vitro and defining the content of the right to reproduction, as they are the elements that will underpin the establishment of acceptable practices to be implemented from the wider area of genetic therapies, stem cells research and ground breaking reproductive techniques, like cloning or solo reproduction.

\section{Acknowledgment}

This paper was elaborated within the doctoral research entitled "Social and Bioethical Acceptance of Techniques Related to Medically Assisted Human Reproduction in Romania", within and with funding by the doctoral scholarship awarded by the Doctoral School of Sociology, University of Oradea, Romania. The research is carried out in co-coordination with the University of Medicine and Pharmacy Grigore T. Popa from Iasi, Romania.

\section{References}

Barac, L. (2014). Câteva considerații privind implicațiile juridice ale tehnicilor de reproducere umană asistată medical (RUAM) [Some considerations regarding the legal implications of medically assisted reproduction techniques (MART)]. Retrieved from

https://www.juridice.ro/311847/cateva-consideratii-privind-implicatiilejuridice-ale-tehnicilor-de-reproducere-umana-asistata-medical-ruam.html

Calhaz-Jorge, C., De Geyter, C., Kupka, M. S., De Mouzon, J., Erb, K., Mocanu, E., Motrenko, T., Scaravelli, G., Wyns, C., \& Goossens,V. (2017). Assisted reproductive technology in Europe, 2013: Results generated from European registers by ESHRE. Human Reproduction, 32(10), 1957-1973. doi:10.1093/humrep/dex264

Celulestem.ro. (n.d.). Cât costă un transplant de celule stem? Retrieved from https://celulelestem.ro/despre-celulele-stem/cat-costa-un-transplant-decelule-stem.html

Cohen, G. (2014). What (if anything) is wrong with human enhancement? What (if anything) is right with it? Tulsa Law Review, 49(3), 465-487. Retrieved from https://pdfs.semanticscholar.org/26fa/35bb3a9183f49eb6246d7e7cb465f 44232a3.pdf

Cojocaru, B. (2010). Primul centru de tratament cu celule stem din România. Retrieved from http://www.mediafax.ro/social/primul-centru-de-tratament-cucelule-stem-din-romania-6131625 
The Need for Specific and Unitary Regulations Regarding Techniques in ... Alexandra HUIDU

Creative Ideas. (2017). Donarea de ovocite este acum posibilă la Clinica Fertilia. Retrieved from https://creativeideas.ro/donarea-de-ovocite-este-acumposibila-la-clinica-fertilia/

Cuc, M. C., Huidu, A., \& Huidu, V. (2010). Pleading for the Implementation of Human Medically Assisted Reproduction and Biotechnologies into the Educational Curriculum. Educația 21, 8.

Farraretti, A. P., Goossens, V., Kupka, M., Bhattacharya, S., De Mouzon, J., Castilla, J. A., Erb, K., Korsak, V., \& Nyboe Andersen, A. (2013). Assisted reproductive technology in Europe, 2011: Results generated from European registers by ESHRE. Human Reproduction, 28(9), 2318-2331, doi:10.1093/humrep/det278

Fertilizare in vitro gratuită 2017. Clinicile incluse, ce cupluri sunt acceptate (n.d.). Retrieved from http://www.totuldespremame.ro/sarcina/conceptie/ fertilizare-vitrogratuita-2017-care-sunt-clinicile-incluse-programul-acoperit-de-stat-cecupluri-sunt-acceptate

Franklin, M., \& Chapman, S. (2000). Human inheritable genetic modifications. Assesing scientific, ethical, religious and policy issues. Washington, SUA. Retrieved from http://www.aas.org/spp/dspp/sfrl/germline/main.htm

Guvernul României. (2013). Hotărârea de Guvern nr. 124/2013 privind aprobarea programelor naționale de sănătate pentru anii 2013 și 2014 [Government Decision no. 124/2013 on the approval of national health programs for the years 2013 and 2014]. Monitorul Oficial al României, 172, 2013, Martie 29.

Guvernul României. (2010). Hotărârea de Guvern nr. 1388/2010 privind aprobarea programelor naționale de sănătate pentru anii 2011 și 2012 [Government Decision no. 1388/2010 on the approval of national health programs for 2011 and 2012]. Monitorul Oficial al României, 893, 2011, Ianuarie 01.

Guvernul României. (2017). Hotărârea de Guvern nr. 155/2017 privind aprobarea programelor naționale de sănătate pentru anii 2017 și 2018 [Government Decision no. 155/2017 on the approval of national health programs for 2017 and 2018]. Monitorul Oficial al României, 222, 2017, Martie 31.

Guvernul României. (2015). Hotărârea de Guvern nr. 206/2015 privind aprobarea programelor naționale de sănătate pentru anii 2015 și 2016 [Government Decision no. 206/2015 on the approval of national health programs for 2015 and 2016]. Monitorul Oficial al României, 208, 2015, Martie 30.

Huidu, A. (2009). Reproducerea umană medical asistată. Etica incriminării versus etica biologică. Studiu de drept comparat [Medically assisted human reproduction. Ethics of incrimination versus bioethics. Comparative law study]. Iași, România: Lumen.

Huidu, A. (2017). Reproducerea umană medical asistată. Etica incriminării versus etica biologică. Studiu de drept comparat [Medically assisted human reproduction. 
Ethics of incrimination versus bioethics. Comparative law study] (2nd ed.). Iași, Romania: Lumen.

Huidu, A. (2018a). The ethics of embrionic stem cells research. The buman being in the early stages of development: A "medicine" or an end in itself? In A. Sandu, A. Funză \& E. Unguru (Coords.), Ethics in research practice and innovation. In printing. Hershey, SUA: IGI Global. doi:10.4018/978-1-5225-6310-5

Huidu, A. (2018b). Tailoring humans: The ethics of genetic engineering In A. Sandu, A. Funză \& E. Unguru (Coords.), Ethics in research practice and innovation. In printing. Hershey, SUA: IGI Global. doi:10.4018/978-1-5225-6310-5

Huidu, A., \& Cuc, M. C. (2009). Norme comunitare in materia biotehnologiilor [Community rules on biotechnology]. Revista de drept comunitar, 4.

Romanian National Institute of Statistics (RNIS). (2012). Evoluția natalităţii şi fertilităţii în România [The evolution of natality and fertility in Romania]. Retrieved from www.insse.ro/cms/files/publicatii/Evolutia\%20natalitatii $\% 20 \mathrm{si} \% 20$ fertilit atii $\% 20$ in $\% 20$ Romania n.pdf

Romanian Parliament. (2006). Legea nr. 95/2006 privind reforma în domeniul sănătății [Law no. 95/2006 on health reform]. Monitorul Oficial al României, 372, 2006, Aprilie 28.

Mihai, A., \& Mirea, C. (2015). România a ajuns la cel mai redus nivel al natalității de după al doilea război mondial. Demografia este o problemă de siguranţă națională Romania has reached the lowest birth rate since the Second World War. Demography is a national security issue]. Ziarul financiar, 2015, Februarie 13. Retrieved from http://www.zf.ro/eveniment/romania-aajuns-la-cel-mai-redus-nivel-al-natalitatii-de-dupa-al-doilea-razboi-mondialdemografia-este-o-problema-de-siguranta-nationala-13818303

Mii de cupluri au depus cerere la Primăria Capitalei pentru programul de fertilizare in vitro [Thousands of couples filed an application with the Nations Capital City Hall for the in vitro fertilization program]. (n.d.). Retrieved from https://stirileprotv.ro/stiri/social/mii-de-cupluri-au-depus-cerere-laprimaria-capitalei-pentru-programul-de-fertilizare-in-vitro.html

Miting pentru familia tradițională la Oradea [Public gathering for the traditional family in Oradea]. (2016, Octombrie 22). Retrieved from http://www.mediafax.ro/social/miting-pentru-familia-traditionala-laoradea-familia-bodnariu-a-fost-prezenta-la-eveniment-s-a-cerut-unreferendum-pe-aceasta-tema-video- 15845435

Neagu, A. (2015). Natalitatea scăzută, problemă de siguranță națională [Low birth rate, a national security issue]. Retrieved from https://revistapresei.hotnews.ro/stiri-subiectele zilei-19169542-vasileghetau-directorul-centrului-cercetari-demografice-academiei-romanenatalitatea-scazuta-problema-siguranta-nationala.htm?nomobile $=$ 
The Need for Specific and Unitary Regulations Regarding Techniques in ... Alexandra HUIDU

Romanian Ministry of Health. (2011). Ordinul Ministrului Sănătății nr. 765/2011 pentru aprobarea Normelor metodologice pentru realizarea si raportarea activitatilor specifice in cadrul subprogramului de fertilizare in vitro [Order of the Minister of Health no. 765/2011 for the approval of the Methodological norms for the development and reporting of specific activities within the in vitro fertilization subprogram]. Monitorul Oficial al României, 378, 2011, Mai 31.

Origyn Fertility Center. (n.d.). Slow freezing sau vitrificare? Retrieved from http://origyn.ro/tag/crioprezervare/

Procedurile prin care trece un donator de spermă [The procedures underwent by a sperm donor]. Adevărul. (2016, Martie 12). Retrieved from https://adevarul.ro/life-style/dragoste-si-sex/procedurile-trece-donatorsperma-cele-mai-ravnite-calitati-costa-materialul-unui-tata-danemarca1 56e2 d4b 65ab6550cb8 bd968c/index.html

Simpson, B. (2001). Making bad deaths good: The kinship consequences of posthumous conception. Journal of the Royal Anthropological Institute, 7(1), 118. doi:10.1111/1467-9655.00047

The Ethics Committee of the American Society for Reproductive Medicine (ECASRM). (2004). Posthumous reproduction. Fertility and Sterility, 82(suppl. 1), 260-262. doi:10.1016/j.fertnstert.2004.05.030)

Ungureanu, A. (2010). Primul centru de tratament cu celule stem [The first center using stem cells treatment]. Curierul National. Retrieved from http://www.curierulnational.ro/Actualitate\%20Companii/2010-0519/Primul + centru + de + tratament $+\mathrm{cu}+$ celule + stem și statisticile prezentate pe site-ul dedicat celulestem.ro, disponibil la: https://celulelestem.ro/banci-celule-stem-romania/celule-stem-bucuresti

United Nations Statistics Division (UNSD). (2016). Demographic yearbook 2016. Retrieved from https://unstats.un.org/unsd/demographic/products/dyb/default.htm 